\title{
Marble cake dreaming of layer cake: the merits and pitfalls of disentanglement in German federalism reform
}

\author{
Sabine Kropp ${ }^{\mathrm{a}}$ and Nathalie Behnke ${ }^{\mathrm{b}}$

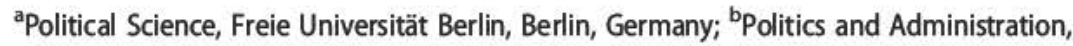 \\ University of Konstanz, Konstanz, Germany
}

\begin{abstract}
This article explains the zigzag of the stepwise federalism reform in Germany by accessing the theoretical concept of institutional incongruity. It is argued that the existing imbalance between competencies, policy problems and fiscal resources was further exacerbated as actors adopted inconsistent institutional 'layers' during the sequential reform. Two case studies on higher education and unemployment policy reveal that actors finally reverted to joint decisionmaking and revived ideas of solidarity in order to remedy inconsistent reform results, although 'disentanglement' and competition had been the leitmotivs underlying the first reform step. The article confirms that institutional congruity is hardly attainable in federations. Reform attempts aiming at disentangling responsibilities and fiscal resources encounter insuperable difficulties, because policy issues more than ever transcend the borders of single territorial units and need joint financing. The study concludes by discussing the question whether joint decision-making - compared to dual resp. 'layer-cake' federalism - owns a specific democratic quality.
\end{abstract}

KEYWORDS Joint decision making; federalism reform; unemployment policy; higher education; Germany

We modernize the federal system, which in itself contains the imperative to cooperate.... we realize that we now enter a period in which we need more cooperation ... (German MPs in the plenary debate of 10 October 2014; BTPIPr. 18/58, at pp.5402, 5394)

\section{Introduction}

In 2016, Germany is looking back on a decade of stepwise federalism reforms. In comparative research, Germany has been classified as a prototype of cooperative federalism and joint decision-making. Nonetheless, the first reform step (2003-06) was strongly inspired from the ideas and goals of dual 
federalism, typically represented by the US (Watts, 2006). Hence, it was aimed at disentangling joint tasks, at separating more neatly the competences of the German Länder and the federal level, at strengthening the accountability of all levels of government, and at introducing a number of competitive elements among the Länder. The second reform step in 2009 introduced the debt brake in order to contain the excessive public debts incurred by most Länder and concomitantly established a stability council supervising their budgetary discipline (see Korioth, this issue). As a third step, an encompassing reform of the half a century old fiscal equalization scheme is to be finished until 2019, when the respective laws will expire. ${ }^{1}$ Ideally, this step will be accomplished by the grand coalition before the Bundestag elections take place in September 2017.

In the light of obvious shortcomings of cooperative federalism, disentanglement, a clearer assignment of powers to the territorial units and more competition became the central vision of the 2006 reform. Joint decision-making as typical of German federalism had widely been criticized because it typically causes long decision-processes, incrementalism and policy solutions at the lowest common denominator (Scharpf, 1988) due to the high number of veto players involved (Tsebelis, 2000, 2002). Dual federalism seemed to be a compelling vision for restructuring the federal architecture, and its advocates apparently tend to dispose of what are regarded as convincing arguments. Along the boundaries of policies, jurisdictions are clearly split between levels of government. This distinct allocation of jurisdictions provides decision-structures transparent to the citizens, secures accountability of political decision-makers and establishes federal competition driving innovation and which is, accordingly, considered to enhance the citizens' living standards. Furthermore, the need for coordination between levels in policymaking such as protection against negative spill-overs is reduced to an absolute minimum. This keeps transaction costs low and protects citizens from unnecessary taxing by the state. Finally, the idea of competition as opposed to solidarity is attractive to the financially stronger states in a federation as it implies less redistribution.

The observation of the 10-year long process of federalism reform in Germany, however, shows that the idea of dual federalism that guided the first reform step did not materialize in the ongoing everyday federal practice. Rather, we observe more financial and responsibility entanglement than before, with the Länder calling even for more. In accordance, some recent reforms have reversed disentanglement; others established new issues of cooperation. Correspondingly, the citation epigraph at the outset of this article indicates that German political decision-makers are even conjuring up a new stage of federal cooperation.

This article contributes to explaining the peculiar zig-zagging reform path. The German example adds concrete evidence to the insight formulated by Grodzins (1966) in the 1960s, arguing that a pure type of dual federalism 
never even existed in the first place. Even with regard to the US, he maintained that American federalism in practice resembled more of a marble than a layer cake. Similarly, Hueglin recently questioned the empirical relevance of the US model (2013). Obviously, the very structure and functioning of federal systems require intense coordination between and among levels of government which is widely incompatible with the layer cake ideal of dual federalism. Beyond this observation, the aim of this article is to elaborate the specific mechanism that recurrently shifts the workings and architecture of federal states from layer cake towards marble-cake structures and processes.

This contribution thus provides a theoretical argument for the particular pattern in the three steps of German federalism reform, which started with a major effort at disentanglement, but subsequently retracted basic elements of the initial reform. Typically, stepwise reforms are prone to dilution. Sequential arrangements create specific challenges to reform consistency and robustness over time because political actors, coalitions and majorities change, and new events and crises demand decisions which may deviate from - or even contradict - former solutions. The advantage of stepwise reforms is that they allow for correcting and refining erstwhile decisions. As such, a deviation from the initial step then is not really surprising. Nevertheless, compared to other federations which have initiated and undergone major constitutional reforms in the last two decades (Benz, 2013), the German case features a particular reform path displaying strong topical inconsistencies, even though the group of reform actors remained consistent and external reform drivers did not substantially change. The German example thus represents an extreme case (Gerring, 2008: 653), exemplifying the tension between cooperation and disentanglement and its effects on the dynamics of federal reform.

In developing the argument, the article proceeds as follows: in the next section, based on a brief review of the literature accounting for institutional reform, a mechanism is outlined that supposedly explains the contradictory evidence of the German reform history. In Section 3, this mechanism is exemplified, tracing the zig-zagging paths through the three waves of federalism reform in the fields of higher education and unemployment care. In Section 4 , lessons are drawn from the comparative case studies, relating them to the analytic framework as outlined in the introduction to this special issue.

While the research question is clearly a positive one, aiming at providing an explanation for an observed puzzle, the implications of this explanation carry normative weight with respect to whether cooperative federalism is merely a 'second-best' alternative to the superior model of dual federalism, something which is not practically attainable; or whether it does have a specific quality of its own which cannot be attained in dual federalism. While this normative debate on the relative merits of the competing models of federalism is not at the heart of this contribution, the implications of the empirical results for 
this normative question are: to wit, whether there is a value in and of itself in the practice of entangled multilevel policy-making, and, if so, then cannot be ignored. We thus conclude the analysis in the last section by feeding the results back into the current theoretical debate (see Behnke and Kropp, this issue).

\section{The role of institutional incongruity in federal dynamics}

There have been numerous attempts to explain the results of the German federalism reforms. Most employ an institutionalist argument, highlighting the reasons for the limited scope of the reforms. These explanatory approaches, however, are unable to account for the specific reform dynamic which shapes the sequence of reform processes. An alternative argument presented in the following paragraphs is based on the notion of institutional incongruity.

Particularly, it was the first stage of federalism reform in Germany that attracted scholarly attention. From an institutionalist perspective, explanations focused on the lack of substantial change in spite of a major reform effort, thereby emphasizing the relative stability of given institutional settings. Researchers highlighted that the reform process revealed the path-dependent development of German federalism (Auel, 2008; Moore and Eppler, 2008). The density of institutions, the existing allocation of powers affording strong veto points, and the high complexity of established rules (Pierson, 2004: 34-37) obviously constrained the institutional designers in their drafting of far-reaching reforms. But even though path dependency can explain the lack of substantial change, it still fails to elucidate why some parts of the already adopted reform were later on replaced.

In a similar vein, the often cited 'joint decision trap' (Scharpf, 1988, 2009) emphasizes the stickiness of entangled federal institutions. More than path dependence, which explores the stability and change of institutions (Mahoney and Thelen, 2010), this application of game theory rather predicts the failure of far-reaching reforms. ${ }^{2}$ But it tells nothing about the reasons why actors resuscitate federal entanglement after having partially disentangled responsibilities. The same is true for approaches based on rational-choice institutionalism, such as veto-player theory (Tsebelis, 2002). By pointing to scenarios in which party actors align their policy positions with those of competing parties ('absorption rule'), the theory helps explain why reforms are adopted despite given veto rights. However, it cannot clarify why actors dismiss out of hand previous policy positions.

Variants of institutionalism highlighting path dependence, the joint decision trap, or veto-player theory are all useful in explaining the limited scope of the reform. Yet, the real puzzle in the long-term analysis of German federalism reform is the observation that - in spite of a clear ideological orientation towards disentanglement - instances of fiscal and 
responsibility entanglement were extended or even newly introduced. Within the institutionalist paradigm, we assume that the zig-zagging reform follows an inherent logic, one driven by the institutional incongruity between responsibilities, the scope of the policy problems and financial resources.

The notion of institutional incongruity is originally borrowed from the theory of public finance. Coase (1960) postulated that a clear distribution of property rights was the precondition for contracts to avoid externalities. In fiscal federalism, institutional congruity denotes that territorial authorities are organized in such a manner that the sets of beneficiaries of a decision, of decision-makers and of cost-bearers are congruent (Oates, 2005: 351; Blankart, 2008: 547-549). Only if a territorial authority is also responsible for paying the expenses necessary to fulfil a public task, will the task be fulfilled efficiently and the preferences of the citizens be best accommodated. When tasks are transferred to subnational levels and when transfers into subnational budgets do not cover expenses, resource scarcity may invite financially weak states to shirk responsibility or, indeed, shift the burden by imposing externalities on other entities of the federation (Bednar, 2009: 155).

In economic analysis, the problem of institutional incongruity can be dealt with in two basic ways: either competences are shifted in a manner so that they become congruent with the effects of a decision and match the financial responsibilities. This strategy would in most cases imply a (re-)centralization of responsibilities in order to internalize external effects and to secure a broader financial capacity. The centralizing strategy is typically justified by the vertical fiscal imbalance that exists in all federal architectures; or financial resources are allocated in such a fashion that empowers subnational entities to bear the costs of the public tasks within their jurisdiction. This strategy is commonly used as an argument for increasing the tax autonomy of states or municipalities and aims at reducing the extent of vertical fiscal imbalance. An increase in tax autonomy, however, does not necessarily mitigate the problem of institutional incongruity for it presupposes that the economic strength of an entity allows raising its revenues effectively by levying new or increasing existing tax rates. In federal states where the economic and financial strength of subnational entities varies substantially, an increase in tax levying or tax varying powers is not always an appropriate remedy to cure institutional incongruity. Rather, the financial capacity of the subnational entities is strengthened by (unconditional or conditional) transfers from the federal level or by granting them a larger share of joint taxes.

These two ways to redress institutional incongruity rely exclusively on the toolkit of economic theory and typically provide a static analysis, pointing at inefficiencies or disequilibria in the allocation of jurisdictions and resources (Olson, 1969; Oates, 2005). In practice, however, a perfect mapping (Oates, 2005: 351) of responsibilities, policy effects and resources is hardly attainable, and a feasible alternative to federal cooperation has not as yet been found. ${ }^{3}$ 
Some tasks, particularly those which increase costs of the modern welfare state, are simply too exorbitant to be shouldered by one federal unit alone. Spill-overs and the multilevel character of numerous policies call for either voluntary federal cooperation or for mandatory joint decision-making, the latter which stipulates cooperation and typically requires qualified majorities or even unanimity. In order to achieve the ever imperfect balance between problems, responsibilities and financial resources, jurisdictions and resources need to be mutually adapted in a continuous process, a route which entails intense coordination and cooperation.

By taking into account the processual nature of creating and redressing institutional incongruity in ongoing processes of constitutional reform, this article broadens the concept's applicability beyond economic theory, thereby linking it to recent theoretical developments of historical institutionalism and highlighting the role of actors and ideas. Political actors take up ideas, because specific concepts seem to respond to current challenges, provide guidance how to solve problems, or warrant legitimacy. Furthermore, we conceive the phenomenon of institutional incongruity in terms of incompatible 'layers' of institutions stemming from different historical or ideational roots.

An argument structurally similar to institutional incongruity was made in historical institutionalist analyses of decentralization processes. Falleti (2005) in her lucid analysis of sequences of decentralization reform in Latin America highlighted the relevance of choosing the 'right' sequence. She pointed out that a transfer of administrative or political competences to subnational entities hindered rather than promoted the decentralization process, particularly if it was not accompanied by a concomitant transfer of fiscal competences (Falleti, 2005: 329). Beyond mere 'sequences' of reform steps, the concept of 'layers' as historically evolving aspects of institutions (Orren and Skowronek, 1994, 2004; Lieberman, 2002) was applied by Broschek (2011) to constitutional reform processes. By regarding constitutions as 'layered', it is possible to deconstruct the different aspects of the complexities of institutions, explaining the change of one layer as historically contingent, even though it may create frictions and incongruity with another layer stemming from another historical and ideational root.

Based on these theoretical considerations, it is expected that specific sequences will emerge in an analysis of reform processes. Initially, an ideologically grounded deviation from the given institutional setting becomes possible if new ideas find a sufficiently large group of supporters and coincide with the rational self-interest of relevant actors involved in the negotiations. The reform then changes one or several layers of the constitution, thus resulting in a departure from the traditional path. This layering effect can create, however, an institutional incongruity between responsibilities, financial resources of territorial authorities and policy problems. From an economic perspective, then, the actors basically have two possible strategies to remedy this incongruity. They 
can either redress the distribution of responsibilities or try to enhance their fiscal autonomy in order to collect the resources needed for the new tasks. From a political point of view, however, both strategies have their drawbacks. A shift of competences back to the central level is unattractive for subnational entities because it hampers their self-esteem and autonomy. An increase in tax autonomy risks increasing existing disparities of economic and financial capacity among the subnational entities. Finally, a major financial transfer from the federal to the subnational level does not bode auspiciously for the federal level because it is quite costly; moreover, it is disadvantageous for the subnational entities since it increases their dependence on the federal level. In practice, it is improbable that a 'purely economic' solution can be implemented. Rather, actors will enter new rounds of negotiation, thereby strengthening mutual entanglement, interdependence and coordination and thus effectively undoing the effect of the initial reform.

\section{One step forward, one step back - reconstructing the zigzag of federalism reform}

The German reform process illustrates the outlined mechanism fairly well. In order to provide more 'grounded' evidence by reconstructing the motives and rationales of the actors involved, two reform cases in the areas of higher education and of unemployment care are analysed. Both of these policy issues belong to the broader field of social policy. In Germany, the logic of the modern welfare state creates intense entanglements - the more so as the constitutional 'postulate of a social state' (art. 20 para. 2 Basic Law) implies general standards and, consequently, strongly interferes with federalism. The cases vividly illustrate the zig-zagging reform path: in both, major reforms were decided in and during the first reform phase (around 2005) and aimed at disentangling more clearly the levels of government. In subsequent years, however, at a sub-constitutional level, those disentanglement reforms were gradually redressed, thereby introducing an even greater financial and competency entanglement than there was before. This mood swing was reinforced by the second constitutional reform in 2009, which introduced the debt brake also for the Länder. The motives and rationale for promoting and supporting subsequent changes and adaptations in legislative processes during a decade of reform are reconstructed in the following through the analysis of parliamentary documents, position papers and expert reports written by practitioners.

\subsection{The 'Collaboration Ban' - disentanglement in higher education}

Higher education is a prolific policy issue for studying the zigzag of German federalism reform because joint decision-making itself became a contested 
issue. During negotiations for the first federalism reform, education policy was the 'stepping stone' leading to the failure of the first reform attempt in 2004. The federal government had tried to encroach upon the exclusive responsibilities of the Länder in education policy and thus the Länder, whose autonomy had been considerably strengthened by a ruling of the federal constitutional court in $2004,{ }^{4}$ made their exclusive jurisdiction conditional for any further negotiation. In order to pass the reform in a second attempt in 2006, the federal government had to make far-reaching concessions to the Länder. Bundestag and Bundesrat finally established the so-called cooperation ban in education policy, aiming at disentangling one of the major constitutional 'joint tasks', with the financially strong states of Bavaria, Hesse and BadenWürttemberg being the drivers of this decision. The term 'cooperation ban' is hyperbole, since the reform did not preclude any cooperation between the federal government and the Länder but substantially constrained it. Basically, in art. 91b Basic Law (new version) only the joint responsibility for financing university buildings was abolished in order to enable the Länder to make investment decisions independently from the federal government. The 'Disentanglement Law' of $2007^{5}$ stipulated that until 2019, the Länder are to be compensated for the abolition of the federal financial aid system for university buildings. Thereafter, however, it is unclear how future investments can be secured. Beyond this, cooperation was still allowed in the following instances: scientific research external to universities; construction of research buildings including large devices (laboratories etc.) at universities as well as for projects in science and research (on the premise that all 16 Länder governments agree in the Bundesrat, thus granting each of them the right to veto); and the preparation and conduct of international comparative surveys on the performance of educational systems.

In light of these restrictions, the federal government remained able to set financial incentives and influence the higher education system according to its political goals. With the Initiative for Excellence (2009), the Pact for Research and Innovation (2005) and the Higher Education Pact (2007), large-scale cooperative projects could be launched (Welsh, 2014). Moreover, the federal government was able to steer the debate on educational standards by emphasizing the so-called PISA surveys, that is, international comparative studies evaluating the performance of educational systems according to art. 91b para. 2 Basic Law. A major problem remained the temporality of cooperation projects, as sustainable solutions and long-term planning were seriously hampered by the given legal basis.

While the Länder had momentarily triumphed to have gained exclusive responsibility for education 'from the cradle to the grave', it soon became apparent that the reform was a pyrrhic victory, because any long time financial support of the universities turned out to be unfeasible. Most Länder have little budgetary capacity for covering existing educational tasks or investing in 
new, innovative ones. Due to the debt brake, the Länder can no longer generate additional revenues by increasing public debts; just few marginal taxes fall under their exclusive jurisdiction (Wieland, 2013: 17, 20). Tuition fees, which had been introduced by a number of Länder after the Federal Constitutional Court had abolished a corresponding framework legislation banning fees in $2005,{ }^{6}$ partially balanced this financial scarcity, but were successively abrogated by the Länder parliaments after students' protests had taken place and a people's initiative against fees was launched in Bavaria in 2013.

Higher education provides an illustrative example for free-riding incentives and incongruities inherent to federal systems (Bednar, 2005) because policy issues often transcend the territorial borders of Länder jurisdictions. Intergovernmental cooperation is a necessity. One state alone cannot exclusively regulate the students' and scientists' mobility. Financially weak Länder in the German North and the East educate students who often subsequently move to the labour markets in the South, where a higher demand for qualified labour attracts graduates from all regions. As a consequence of this interregional migration of qualified labour, the poorer Länder effectively produce a public good to the benefit of the richer ones. Not surprisingly, financially weak Länder governments soon claimed to recalibrate the existing rules, while the stronger ones, such as Hesse, Baden-Württemberg, or Bavaria, refused any extension of federal authority on education policy. ${ }^{7}$

In July 2014, the federal minister of education, Johanna Wanka (Christian Democratic Union [CDU]), finally introduced a constitutional amendment. ${ }^{8}$ By offering a package deal, the minister succeeded in avoiding the veto and abstention of those Länder in the Bundesrat which had feared federal encroachment on higher education. As from the end of 2014, the federal government covered $65 \%$ of the costs for the general students' financial assistance (BAFöG; art. 104a Basic Law). The federal government offered to take over the remaining $35 \%$ share of the Länder and to terminate mixed financing. ${ }^{9}$ As a tandem measure, this offer was linked to the Länder's support of the constitutional revision and declared to expire by the end of $2014 .{ }^{10}$ The federal government grants additional 1.17 billion Euros per year to the entirety of the Länder which are free to set their own priorities on preschool, elementary or secondary education, or university building, with the caveat, however, that universities should receive the lion's share. In order to prevent Länder governments from transferring the money to their general budgets, they were committed to invest it exclusively for education. ${ }^{11}$ Yet, the Bundestag's budget committee expressed its mistrust by asking the federal government to monitor the allocation. ${ }^{12}$ Indeed, first evaluations reveal that not all Länder have complied with the agreement. ${ }^{13}$

Finally, the 16 Länder governments unanimously adopted the constitutional amendment in the Bundesrat. ${ }^{14}$ In the Bundestag, the bill was supported by the grand coalition, ${ }^{15}$ whereas the opposition abstained from 
voting. ${ }^{16}$ The new article $91 \mathrm{~b}$, Basic Law, which replaced the 'cooperation ban', stipulates that the federation and the states are allowed to cooperate in cases of nationwide importance in order to facilitate science, research and teaching. ${ }^{17}$ If universities are affected, all 16 Länder must agree. Even though the necessity for the constitutional amendment was uncontested, the opposition criticized that the vague legal term 'nationwide importance', which has to be substantiated by an agreement of the federation and the Länder, ${ }^{18}$ somewhat implies that the federal government funds the excellence initiative on a longlasting basis, while a proposal for a solid basic funding of higher education was tabled indefinitely. Moreover, the unanimity clause was controversially debated, since it gives any state the opportunity to veto projects launched by a majority of the Länder and thus abets problematic package deals. However, unanimity is set in stone as it prevents the federal government's encroachment onto the exclusive state responsibilities. ${ }^{19}$ With the package deal, the Länder allowed the federal government to co-finance their tasks in order to overcome financial scarcity, but then in return compensated its increased role by obtaining additional funds not earmarked for certain projects. In other words, the Länder accepted a growing influence of the federal government in higher education by strengthening federal cooperation, but were able to exchange it with a disentanglement of the BAFöG's mixed financing. In fact, this adjustment contributes to reduce incongruity problems and concomitantly increases the financial scope of the Länder.

Evaluating the arguments brought forward in the plenary debates on the 'cooperation ban' and by the Länder governments, it is conspicuous that resource scarcity worked as the primary driver for strengthening entanglement in higher education. The debt brake as the core element of the second reform step, which functioned as a new institutional layer, considerably enforced already existing incongruities between the recently extended state responsibilities and limited fiscal resources. Territorial spill-overs in higher education, by contrast, were occasionally perceived as a problem during the political debate, ${ }^{20}$ but in the end played a minor role. When assessing the ideational background of the debate, a significant change comes to the fore. After the leading discourse had been on disentanglement and federal competition for about two decades, the political debate remarkably returned towards the notions of cooperation and social justice.

Tracing the zig-zagging path through the lens of the plenary debates, one encounters three interrelated arguments: firstly, the 'cooperation ban' is predominantly labelled as a 'great mistake', ${ }^{21}$ 'nonsense ${ }^{\prime 22}$ and a 'meander'. ${ }^{23}$ Strikingly, representatives used social justice as a normative yardstick for evaluating policy instruments when arguing in favour of federal cooperation. ${ }^{24}$ Balancing inter-regional differences is seen as a necessary condition for equalizing opportunities for individual advancement. Secondly, German politicians 
across the party camps highlight that institutions should allow for long-term federal cooperation, that there has never been as much cooperation as in the present and that the need for federal cooperation will further increase. Some MPs explicitly conjure up the 'spirit' or 'culture' of cooperation sustainably shaping the German federation as opposed to the US model of dual federalism. ${ }^{25}$ Thirdly, although cooperation was generally revitalized as leitmotiv by the Länder and the Bundestag's party groups, party differences are still visible. The CDU/Christian Social Union (CSU) downplayed the negative consequences of the 'cooperation ban' suggesting that the constitutional revision would thus only aim at recalibrating opportunities for cooperation. ${ }^{26}$ The Social Democratic Party (SPD) regretted that school policy was excluded from the compromise, but as a party in government supported the bill. In contrast, the parties in opposition, that is, the Green and the Left which, for historical reasons, have weaker federal roots than the CDU/CSU, highlighted the need to overcome scattered regionalism and are more inclined to accept a centralization of tasks which is seen as alternative to federal competition. Altogether, the case of higher education signals a remarkable U-turn. Joint decision-making and cooperation are no longer regarded as obstacles to effective policy-making, but valued as means for balancing incongruities, while avoiding simple centralization.

\section{2. 'Hartz IV' - disentanglement in unemployment policy}

A second instructive illustration of the emergence of institutional incongruity as a result of institutional layering is provided by the reform of unemployment and social benefits under the heading of 'Hartz IV reform'. ${ }^{27}$ Almost simultaneously to the negotiations for the first federalism reform (2003-05), the 'Hartz IV reform' (passed in ordinary legislative procedure in 2003 and entered into force in 2005$)^{28}$ laid the foundation for a major financial and organizational joint execution of tasks between the federal and the municipal levels.

The 'Hartz' reforms grew out of a major social democratic reform agenda ('Agenda 2010') in an effort to modernize the German welfare state, to reduce the financial burden for the state and concomitantly to revive the labour market. The fourth labour market reform package ('Hartz IV') united extended unemployment and social benefits into one administrative unit. Before the reform, three distinct benefits had existed: unemployment insurance payments (paid for a limited time, now called unemployment benefits type I and restricted to 18 months); tax paid unemployment benefits for long-term unemployed who received no more insurance payments, and which is paid for by the Federal Labour Agency; and social care paid for by the municipalities. ${ }^{29}$ With the reform, the latter two benefits were united to so-called unemployment benefits type II, and were paid for by the Federal 
Labour Agency while the municipalities bore the benefits for heat and rent for recipients of type II payments. Under this measure, it was hoped to substantially relieve the financial burden for the municipalities (Hassel and Schiller, 2010: 112; Henneke, 2014: 68), which from the 1990s on had been seriously suffering under the continuously rising expenses for welfare benefits.

The new 'Hartz IV' regulations increased federal entanglement in two respects. Institutionally, they established a new organizational unit at the municipal level, the so-called job centres for administering the new services and payments to the citizens. Those job centres, at least in their standard form, are joint administrations, uniting under one roof a municipal (following the tradition of the municipal responsibility for paying social care) and a federal administration (following the tradition of the federal responsibility for unemployment benefits). This double-hatted administration runs counter to a basic principle for the distribution of tasks in the German federal system which forbids mixed administrations (Remmert, 2008). Financially, because they assigned costly tasks to the municipal level (costs for the municipal part of the personnel and the organization as well as of costs for the heat and rent benefits), they created a considerable and long-lasting financial burden for the municipalities (more specifically for the counties) without providing for an adequate compensation.

Only shortly after the Hartz IV law, the first federalism reform prohibited the direct assignment of tasks from the federal to the municipal level. In such situations when tasks had been assigned directly from the federal to the municipal level - which had occurred frequently before 2005 - the Länder authority of assigning tasks was circumvented, thus quashing the principle of connectivity between the Länder and their municipalities. As a consequence, nobody was directly responsible for paying for those tasks, effectively leaving the municipalities in a situation of helplessness (Henneke, 2006). As a major achievement of the first federalism reform, this regulatory gap was closed by a reformulation of art. 84 para. 1 (7) and art. 85 para. 1 (2) Basic Law which now expresses an explicit ban on direct assignments of tasks from the federal to the municipal level. In this sense, the reform of art. 84 and 85 Basic Law resulted in a clearer distinction between federal and Länder spheres of authority and re-established the protective relationship between the Länder and their municipalities, securing the financial endowment of the latter based on the principle of connectivity. ${ }^{30}$ All federal laws, however, that predated the reform and established municipal tasks, retained their validity (art. 125a Basic Law); this also applied to the Hartz IV law.

While the reform had been introduced with the expectation to reduce the municipalities' financial burdens because they no longer had to pay for social welfare benefits, that hope was futile as municipal expenses for social purposes kept rising continuously even after $2005 .{ }^{31}$ In this situation of exacerbated institutional incongruity, then, the levels of government had to find 
creative solutions for closing the municipalities' financial gap, all of which created, however, new instances of fiscal entanglement between the levels of government.

Firstly, even in the first year (2005), the federal level subsidized municipal costs for heat and rent by $€ 3.5$ billion. What had initially been intended to be a loan to be repaid later by the municipalities was soon understood to become a recurrent stream of payments by the federal level to support the municipalities who saw no end in containing the rising welfare costs. Since 2005 , the municipalities were subsidized by varying degrees, receiving roughly one-third of their costs for heat and rent and a continuously increasing share of their costs for basic social support for the elderly and not fully employed ('Grundsicherung im Alter und bei Erwerbsminderung') (Geißler and Niemann, 2015: 10). Secondly, the Hartz IV reform impacted differently on the Eastern and Western Länder, because the expenses for welfare benefits had been distributed rather unevenly across the territory - the East German Länder had the highest rates of unemployment receivers, but almost no receivers of welfare benefits, whereas the relationship was reversed in the West. Thus the Eastern Länder could profit financially far less from the abolition of municipal welfare payments, but had to incur higher costs for heat and rent. In order to compensate for those uneven consequences of the Hartz IV law, the fiscal equalization law was changed, introducing a new fiscal flow to the Eastern Länder which were compensated by a fixed amount of $€ 1$ billion yearly for a period of six years and decreasing amounts from then on ( $\$ 11$ section 3a fiscal equalization law, see also Henneke, 2014: 68). Thirdly, in 2011 a new law for strengthening the financial capacity of the municipalities was passed, which increased the share of federal payments for basic social support for the elderly and not fully employed up to $100 \%{ }^{32}$ Fourthly, in 2015, a new law raised the federal subsidy from 2015 until 2018 for an additional $€ 5$ billion until 2019 according to the revised version of $\S 46 \mathrm{sec}$. 5 Social Law Book II, and the federal share of the municipal costs for heat and rent was increased by another $€ 500$ million. $^{33}$

As a result, horizontal and vertical financial entanglements in welfare payments were continually tightened. But even the organizational entanglement - the establishment of a mixed administration in the job centres - was confirmed. Actor constellations and interests in this case followed more territorial units than party lines: the counties filed a suit in front of the federal constitutional court against the job centres, arguing that the mixed administration diluted responsibilities. Indeed, the federal constitutional court played - as in the higher education case - an important role in putting pressure on the political actors. It had declared the job centres to be unconstitutional and prompted the federal legislator to remedy this unconstitutionality by $2010 .^{34}$ The reaction of the Bundestag was, however, slightly different than what many observers might have expected, as it changed the constitution 
by inserting a new joint task in Art. 91e. ${ }^{35}$ In this decision, party conflicts were largely suspended. In spite of intense protest by municipalities and counties, the federal legislator thus showed that it preferred to provide a constitutional foundation for the continued existence and working of a mixed administration instead of administratively disentangling the execution of this task by giving it entirely into the hands of the counties.

How can this ideological preference which runs completely contrary to the initial aim of disentanglement be explained? In terms of the new instances of financial entanglement, the answer clearly lies in the problem of institutional incongruity. Public and political debates that accompanied the numerous legislative and judicial acts made it very clear that the major concern - across party interests - was constantly how to equip the municipalities with sufficient financial means. In terms of institutional entanglement by new joint tasks, the federal level was unwilling to divest itself of the means to control the execution of this important branch of the welfare state. Because social transfer payments amount to the major share of public expenses, they cannot be left to the Länder level alone. Since the municipalities and counties execute welfare laws, the federal level cannot handle it alone either. Consequently, a close-knit entanglement is built into the very structure of the modern welfare state.

\section{The incongruity of competences and finances - lessons from the comparative case analysis}

The mechanisms behind the zig-zagging path in the cases presented support of the general description in Section 2: in the beginning, an overarching coalition of actors aligns along an ideological paradigm, enabling a reform that causes a departure from the given institutional path. In the case of higher education, this reform coalition was mainly formed by liberal and conservative parties, neoliberal think tanks and donor Länder in the fiscal equalization scheme. Problem definitions focused on the ossification of the federal architecture due to the deadlock in the Bundesrat (see Stecker, this issue), on increased economic, political and cultural disparity since unification, and an increasingly regionalized party system (see Detterbeck, this issue). By emphasizing the values of dual and competitive federalism and by claiming more disentanglement between territorial levels to secure transparency and accountability, an alternative vision of federalism was promoted which offered seemingly attractive answers to the questions 'how much unity and diversity' and 'diversity or unity of what?' Similarly, in unemployment care, the ideas of the 'activating state' and the 'third way' had great appeal far beyond the SPD, because it emphasized corresponding values of autonomy and responsibility. 
Subsequently, as a consequence of the reform, the neat separation of legislative competences and clear ascription of tasks soon betrayed the expectations when it came to everyday policy-making. While responsibilities had been shifted to lower levels of government, this was not accompanied by correspondingly enlarged financial means, thus creating a problem of incongruity between different institutional layers. In this situation, the European economic, monetary and debt crises overlapped with the existing problem, acting as an external trigger for the second reform step and concomitantly increasing institutional incongruity. On the one hand, costs for the newly gained policy responsibilities in the education and social transfer sectors increased significantly during the crisis; on the other, the tightened economic situation dictated that there is a new paradigm of fiscal austerity and debt ceilings, popularizing the debt brake and further restricting the Länder in their options to generate income. In the light of the expiring financial equalization law (end of 2019) and the debt brake's entry coming into force (2020), Länder and municipalities for the third step of federalism reform urgently need a reliable fiscal framework to count on for the coming years. In this situation, the financially weaker Länder - that is, the clear majority - request neither more autonomous fiscal competences nor do they want the federal level take back their responsibilities. Rather, they demand more financial support from the federal budget, thereby stressing the value of solidarity while graciously ignoring that the instances of joint decision-making and co-financing that they had so proudly abolished before were now re-introduced.

As could be shown, triggers for the different reform steps stemmed from changing perceptions of problem constellations - the dysfunctionality of the federal architecture, the European crisis and the constantly rising costs of the welfare state - and were interpreted in analogous ideological paradigms entailing contradictory visions of federalism: first disentanglement, autonomy and competition, then fiscal austerity and conditionality, and finally solidarity and joint responsibility. An overarching vision of the direction in which German federalism ought to develop and which could have linked the contradicting institutional layers of the federal system coherently was obviously lacking (see Benz, this issue). While the content and direction of the reforms zig-zagged along their ideological underpinnings, actor constellations did not noticeably change across the reform steps. For all reforms, effectively a grand coalition of Christian and Social Democrats, which since 2013 has had to be supported by the Green party which is part of several Länder coalitions, was needed to pass legislation in both chambers. The entirety of the Länder finally supported the throwback to and strengthening of federal entanglement. Altogether, the reform path can be interpreted as rational reactions of the involved actors to external circumstances and 'home-made' situations of institutional incongruity resulting from a layered, sequential reform. 


\section{Concluding discussion}

The analysis allows reassessing the quality of entangled federalism. As Grodzins $(1966)$ and Hueglin $(2000,2013)$ note, entanglement seems to be almost unavoidable in multilevel systems. The economic ideals of institutional congruity, fiscal equivalence (Olson, 1969) and connectivity (see Blankart, 2008: 548) are not feasible under real-life conditions. Particularly, the public tasks of the modern welfare state, and similarly the modern challenges of global environmental problems, terrorism or cyber security, cannot be tackled by single territorial units. Rather, in order to contain negative externalities and to exploit economies of scale and synergetic effects, intense cooperation and coordination as well as joint financing of tasks seem to be the order of the day. These findings also apply for dual federalism, such as Switzerland, where federal cooperation was not coincidentally fixed as a constitutional imperative in 2006, even though the cantons still have the right to deviate from compromises.

Still, the ideals of layer-cake federalism and institutional congruity retain their initial appeal, promising democratic accountability, allocative efficiency and transparency for the citizens. Is the real-life marble-cake federalism thus just a second-best solution to the non-attainable ideal of layer-cake federalism? This article contends that this is not the case. Marble-cake federalism provides a normative quality of its own. One may rightly argue that intergovernmental cooperation also characterizes layer-cake federalism. However, it does make a difference whether cooperation remains voluntary, thereby enabling federal units to pursue their own policies if they do not agree to a common solution, or whether joint decision-making makes cooperation mandatory. While it is true that joint decisions blur responsibilities to the voter and often provide policy solutions reflecting the lowest common denominator, they are, at the same time, more inclusive on the input-side of legitimacy and more sustainable on the output-side.

On the input-side, the concept of joint decision-making, which stipulates that oversized majorities have to be included into the political process, thereby protecting federal units and their citizens from being overruled, shows striking analogies to prominent theories of democracy (Dahl, 1973; Lijphart 1999). These place most emphasis on inclusion, foregrounding the broad representation of citizens which has its own democratic quality. On the output-side, for many policy issues, a concluding solution cannot be found. Problems are difficult to define, targets move, and actors as well as voters' preferences change over time. In such situations, conflicts cannot be ultimately solved by a singular decision but, in the sense of Hueglin's 'treaty federalism' (2000, 2013) or Taylor's 'procedural liberalism' (1992), need to be accommodated in a continued discourse. Joint decision-making provides institutionalized opportunities to keep an issue on the political agenda. It 
enables actors to continuously process policy problems, albeit it often creates just temporary and small-scale solutions. In other words, even though joint decision-making undoubtedly obscures accountability, decreases transparency, and typically leads to incremental policy-making, it nonetheless possesses a specific quality which is often underestimated but should be weighed against its deficiencies.

\section{Notes}

1. See the law on general standards (BGBI. I, 9 Sep 2001, p.2302), the law on fiscal equalization, and the law on continuing the Solidarity Pact (see BGBI. I, 20 Dec 2001, p. 3955).

2. With a critical stance see Benz 2005, 2008.

3. Boundary modifications or 'Functional Overlapping Competing Jurisdictions' (Frey and Eichenberger, 1996) have widely been discussed as possible solutions. Whereas the first option is hard to achieve in Germany due to constitutional hurdles stipulated by art. 29 Basic Law and to reasons of political rationality, the second downgrades the territorial structuring of federalism and can partially be realized at best.

4. See decision of the Federal Constitutional Court on the 'junior professors', 2 BvF 1/03, 2 BvF 2/02, 27 July 2004.

5. BGBI. I, 2098, 2102.

6. See decision of the Federal Constitutional Court 2 BvF 1/03, 26 Jan 2005.

7. See http://www.stuttgarter-nachrichten.de/inhalt.bildungsbereich-abschaffungdes-kooperationsverbotes.9e358d03-8ca7-458f-a740-78c64ba3e94c.html; http://www.spiegel.de/unispiegel/studium/bildungsfoederalismus-das-kooperationsverbot-kippelt-a-814584.html (accessed 5 Aug 2015).

8. BT-Drs. 18/2710.

9. See the draft bill, BT-Drs. 18/2663; BT-PIPr. 18/57.

10. BT-PIPr. 18/57.

11. See BT-Drs. 18/3359; response of the federal government to the minor interpellation of the Left party.

12. See BT-PIPr. 18/66, at p.6231.

13. See http://www.deutschlandfunk.de/hochschulpolitik-frei-gewordene-geldervon-laendern-nicht.680.de.html?dram:article id=320375 (accessed 5 Aug 2015).

14. BR-Drs. 570/14, decision on the amendment of the Basic Law (art. 91b).

15. Originally, the SPD had proposed to include school financing and advocated a new Art. 104c Basic Law in order to realize durable federal financing.

16. BT-PIPr. $18 / 66$, at p.6237.

17. Draft bill of the federal government, BT-Drs. 18/2710; BR-Drs. 323/14.

18. See BT-Drs. $18 / 2710$, at p.7.

19. Standing committee for education, research and technological impact assessment, recommendation for decision and report, see BT-Drs. 18/3141, at pp.10, 11, 13; BT-PIPr. 18/26, at p.2044.

20. See the statement of the minister president of Saxony-Anhalt Rainer Haseloff, http://www.welt.de/print/die welt/article128361059/Haseloff-dringt-auf-neuenFinanzausgleich.html (accessed 31 July 2014).

21. BT-PIPr. 18/58, at pp.5390, 5400.

22. BT-PIPr. 18/66, at p.6231. 
23. BT-PIPr. $18 / 66$, at p.6228.

24. See, for instance, BT-PIPr. 18/58; BT-PIPr. 18/66; BT-PIPr. 18/57.

25. See, for instance, BT-PIPr. 18/66, at p.6277.

26. See BT-PIPr. 18/58, at pp.5384, 5402.

27. The reform was nicknamed 'Hartz IV', because Peter Hartz, a businessman, chaired a governmental reform commission 'modern services for the labour market' established in 2002. The commission produced a series of reform proposals for modernizing social policy. The largest and politically most controversial fourth reform proposal concerned the social law books no. II and XII with the initiative to join unemployment benefits and social security payments.

28. Fourth Law for Modern Services at the Labour, BGBI. I, pp.2954-2955 of 24.12.2003.

29. The term 'municipalities' is used as an umbrella term for different territorial units at the lowest level of government, including cities, boroughs and counties. It is the counties, however, who administer and pay for unemployment benefits.

30. Furthermore, by establishing the right of the Länder to deviate in their regulation of administrative units and procedures from federal laws (art. 84 para. 1 ( 2 and 3 ) - this provision parallels the concomitant regulations on deviation rights in legislation in art. 72), the reform of the article also aimed at reducing the number of consent laws in the Bundesrat.

31. In 2004, the municipalities had total expenses above $€ 32$ billion for social benefits, which amounted to above 20\% of their budgets, and in 2015 nearly $€ 50$ billion, amounting to more than $24 \%$ of their budgets, see Geißler and Niemann (2015: 22-23).

32. Social payments 'Grundsicherung im Alter und bei Erwerbsminderung' were to be paid to $45 \%$ by the federal level ( $€ 1.2$ billion) in 2012 (BT-Drs. 17/7402).

33. Law on the promotion of investments in municipalities with low fiscal capacity and to relieve the Länder and municipalities when accommodating asylum seekers, BT-Drs. 18/4975 of 20 May 2015.

34. Sentence of the federal constitutional court of 20.12.2007 (2 BvR 2433/04, 2 BvR 2434/04).

35. BT-Drs. 17/1554, entering into force on 21 July 2010.

\section{Acknowledgements}

We would like to thank the reviewers for their constructive comments on this paper.

\section{Disclosure statement}

No potential conflict of interest was reported by the authors.

\section{References}

Auel, K. (2008), Still no exit from the joint decision trap: the German federal reform(s), German Politics, Vol.17, No.4, pp.424-439.

Bednar, J. (2005), Federalism as a public good, Constitutional Political Economy, Vol.16, No.2, pp.189-205.

Bednar, J. (2009), The robust federation. Principles of design. Cambridge: Cambridge University Press. 
Benz, A. (2005), Kein Ausweg aus der Politikverflechtungsfalle? Warum die Bundesstaatskommission scheiterte, aber nicht scheitern musste, Politische Vierteljahresschrift, Vol.46, No.2, pp.204-214.

Benz, A. (2008), From joint decision traps to over-regulated federalism - adverse effects of a successful constitutional reform, German Politics, Vol.17, No.4, pp.440-456.

Benz, A. (2013), Balancing rigidity and flexibility: constitutional change in federal systems, West European Politics, Vol.36, No.4, pp.726-749.

Blankart, C.B. (2008), Öffentliche Finanzen in der Demokratie (7 ed). München: Vahlen.

Broschek, J. (2011), Conceptualizing and theorizing constitutional change in federal systems: insights from historical institutionalism, Regional and Federal Studies, Vol.24, No.4-5, pp.539-559.

Coase, R.H. (1960), The problem of social cost, Law and Economics, Vol.3, October, pp.144.

Dahl, R.A. (1973), Polyarchy: Participation and Opposition. New Haven, London: Yale University Press.

Falleti, T.G. (2005), A sequential theory of decentralization: Latin American cases in comparative perspective, American Political Science Review, Vol.99, No.3, pp.327-346.

Frey, B.S. and Eichenberger, R. (1996), FOCJ: competitive governments für Europe, International Review of Law and Economics, Vol.16, No.3, pp.315-327.

Geißler, R. and Niemann, F.-S. (2015), Kommunale Sozialausgaben - wie der Bund sinnvoll helfen kann. Gütersloh: Bertelsmann-Stiftung.

Gerring, J. (2008), Case selection for case study analysis: qualitative and quantitative techniques, in J. Box-Steffensmeier, H.E. Brady and D. Collier (eds), Oxford Handbook of Political Methodology, pp.645-684. New York: Oxford University Press.

Grodzins, M. (1966), The American System: A new View of Government in the United States. New Brunswick, NJ: Transaction Publishers.

Hassel, A. and Schiller, C. (2010), Sozialpolitik im finanzföderalismus - Hartz IV als Antwort auf die Krise der Kommunalfinanzen, Politische Vierteljahresschrift, Vol.51, No.1, pp.95-117.

Henneke, H.-G. (2006), Die Kommunen in der Föderalismusreform, Deutsches Verwaltungsblatt, Vol.121, No.14, pp.867-871.

Henneke, H.-G. (2014), Neuordnung der Aufgaben und der zugehörigen Finanzströme: Beispiele rund ums SGB II \& XII, in M. Junkernheinrich and J. Lange (eds), Föderale Finanzen. Auf dem langen Weg zu Einer Reform, pp.65-78. Loccum: Evangelische Akademie Loccum.

Hueglin, T. (2000), From constitutional to treaty federalism: a comparative perspective, Publius: The Journal of Federalism, Vol.30, No.4, pp.137-153.

Hueglin, T. (2013), Treaty federalism as a model of policy making: comparing Canada and the European Union, Canadian Public Administration, Vol.56, No.2, pp.185-202.

Lieberman, R.C. (2002), Ideas, institutions, and political order: explaining political change, American Political Science Review, Vol.96, No.4, pp.697-712.

Lijphart, A. (1999), Patterns of Democracy: Government Forms and Performance in Thirtysix Countries. New Haven: Yale University Press.

Mahoney, J. and Thelen, K. (2010), Explaining Institutional Change. Ambiguity, Agency, and Power. Cambridge: Cambridge University Press.

Moore, C. and Eppler, A. (2008), Disentangling double politikverflechtung? The implications of the federal reforms for bund - länder relations on Europe, German Politics, Vol.17, No.4, pp.488-508.

Oates, W.E. (2005), Towards a second-generation theory of fiscal federalism, International Tax and Public Finance, Vol.12, No.4, pp.349-373. 
Olson, M. Jr. (1969), The principle of "fiscal equivalence": the division of responsibilities among different levels of government, American Economic Review, Vol.59, No.2, pp.479-487.

Orren, K. and Skowronek, S. (1994), Beyond the iconography of order: notes for a "new institutionalism", in L.C. Dodd and C. Jillson (eds), The Dynamics of American Politics, pp.311-330. Boulder, CO: Westview Press.

Orren, K. and Skowronek, S. (2004), The Search for American Political Development. Cambridge: Cambridge University Press.

Pierson, P. (2004), Politics in Time. History, Institutions, and Social Analysis. Princeton, NJ: Princeton University Press.

Remmert, B. (2008), Rechtliche Grundlagen der Zusammenarbeit zwischen Bund und Ländern im bereich der Verwaltung, in $\mathrm{H}$. Scheller and J. Schmid (eds), Föderale Politikgestaltung im Deutschen Bundesstaat, pp.36-49. Baden-Baden: Nomos.

Scharpf, F.W. (1988), The joint-decision trap: lessons from German federalism and European integration, Public Administration, Vol.66, No.3, pp.239-278.

Scharpf, F.W. (2009), Föderalismusreform. Kein Ausweg aus der Politikverflechtungsfalle? Frankfurt/New York: Campus.

Taylor, C. (1992), Multiculturalism and the "Politics of Recognition". Princeton, NJ: Princeton University Press.

Tsebelis, G. (2000), Veto players and institutional analysis, Governance, Vol.13, No.4, pp.441-474.

Tsebelis, G. (2002), Veto Players: How Political Institutions Work. New York/Princeton, NJ: Russell Sage Foundation/Princeton University Press.

Watts, R.L. (2006), Comparing Federal Systems. Montreal: McGill-Queen's University Press.

Welsh, H.A. (2014), Education, federalism and the 2013 bundestag elections, German Politics, Vol.23, No.4, pp.400-414.

Wieland, J. (2013), Neuordnung der Finanzverfassung nach Auslaufen des Solidarpakts II und Wirksamwerden der Schuldenbremse. Speyer: Deutsche Universität für Verwaltungswissenschaften. 